\title{
ИСТОРИЯ ПРАВОВОГО РЕГУЛИРОВАНИЯ ЛОТЕРЕЙ в РОсСИИ
}

Аннотация: В настоящей статье автор рассматривает историю правового регулирования лотерей в России. Статья условно разделена на три исторических периода: дореволюиионный период, советский период и современную Россию. Автор подробно рассматривает каждый из них в отдельности, отмечая особенности и закономерности каждого из них. В коние статьи автор делает выводы, характеризующие правовое регулирование лотерей в России на каждом этапе развития отечественного законодательства.

Ключевые слова: Юриспруденция, лотерея, игра, азарт, выигрыш, Россия, история, правовое регулирование, благотворительность, риск

Л отерея имеет весьма почтенную историю. По разным свидетельствам, первые лотереи появились в Древнем Вавилоне, Древнем Китае, Древней Греции и Риме. Деятельность по организации и проведению лотерей со временем попадали под правовую регламентацию законов тех государств, в которых проводились лотереи.

В нашей стране лотереи появились сравнительно недавно, и они, безусловно, не могли остаться без внимания отечественного законодателя.

Историю правового регулирования лотерей в России следует рассматривать в привязке к историческим периодам, разделившим историю нашего государства.

\section{Правовое регулирование лотерей в дореволюционный период}

В России первая лотерея была проведена в ноябре 1700 года во время царствования Петра $\mathrm{I}^{1}$. Так, по свидетельству И.А. Желябужского, Яков Андреевич Гассениус, часовых дел мастер, организовывает некое «счастливое воспытание», «по-иноземечески называемое «лотери» в 80 рублев лот с числами, где всем охотникам и охотницам вольно свою часть испытать, како добыть тысячу рублев за гривну». Данное мероприятие очень напоминало моментальную лотерею: два ребенка вытаскивали счастливые билетики («два младенца, которые не видовавши все лоты или ярлыки, перед теми свидетелями и народом, кто желает быть, перед всеми будут вынимать»), на которых было указано, «сколько денег написано»². Сам Гассениус забирал себе по одной копейке с гривны от выигрыша. Очевидно, что лотерея носила ярко выраженный коммерческий характер, целью лотереи являлось извлечение прибыли.

${ }^{1}$ Маргвелашвили В. Первая лотерея на Руси // Молодая гвардия. 1967. № 3. C. 188.

2 Записки Желябужского с 1682 по 2 июля 1709 г.. СПб.: Типография Императорской Российской Академии, 1840. С. 151-154.
Однако надо признать, что в целом историческое событие - первая российская лотерея, по сути, осталось незамеченным, и государственное регулирование организации и проведения лотереи не требовалось.

Другое интересное мероприятие было проведено в 1745 году - лотерея, в которой разыгрывались описанные за казенные долги товары и вещи одного из купцов 3 .

В середине XVIII века просвещенное российское общество увлекается благотворительностью. Именно в это время зародилось такое великосветское развлечение, как художественные лотереи ${ }^{4}$, которые представляли собой финансовые операции, состоящие из продажи нумерованных билетов, розыгрыша предоставленных предметов и вручения выигрышей 5 .

15 июля 1760 г. издается Сенатский указ, с приложением Высочайше утвержденного плана «Об учреждении Государственной лотереи, для содержания отставных и раненых обер-и унтер-офицеров и рядовых». Доходы от лотереи направляются на содержание отставных и раненых обер- и унтер-офицеров и рядовых. А.В. Сохан называет данный указ первым правовым актом о лотерея $x^{6}$. Вместе с тем Сенатский указ 1760 года нельзя назвать источником правового регулирования лотереи, а носит ненормативный характер, поскольку посвящен лишь организации одной конкретной лотереи.

\footnotetext{
3 Энциклопедический словарь / под ред. проф. И. Е. Андреевского. Санкт-Петербург: Ф. А. Брокгауз, И. А. Ефрон, 1890-1907. Т. 18. Лопари - малолетние преступники. 1896. С. 28.

${ }^{4}$ Северюхин Д.Я. Художественный рынок Санкт-Петербурга-Петрограда - Ленинграда, его роль и значение в истории развитии отечественного изобразительного искусства // Автореф. дис. ... докт. иск.. наук. М., 2010. С. 38.

${ }^{5}$ Северюхин Д.Я. Художественный рынок Санкт-Петербурга Петрограда - Ленинграда, его роль и значение в истории развитии отечественного изобразительного искусства // Дис. ... докт. иск.. наук. М., 2010. С. 629.

${ }^{6}$ Сохан A.B. Правовое регулирование лотереи в Российской империи // История государства и права. 2011. № 12. С. 2.
} 
Однако в стране постепенно получают распространение лотереи коммерческие, проводимые уже в целях обогащения частных лиц, их организовывавших.

Чуть позже был принят Сенатский указ от 7 декабря 1760 г. «О конфисковании товаров, кои носят по домам для играния лотереи».

Как указывает А. Иванов, в «Санкт-Петербургских ведомостях» в январе 1761 года, в кратковременное царствование Петра III опубликовано одно из первых официальных строгих предупреждений: «Сим объявляется, чтоб имеющие хождение по домам с посудою и другими товарами для играния лотереи, впредь по домам не ходили, под опасением конфискования как посуды, так и всех товаров» ${ }^{7}$

Императрица Екатерина II, заметив, что объявленная в 1760 году Государственная лотерея, для содержания отставных и раненых обер- и унтер-офицеров и рядовых не только не принесла ожидавшихся выгод, но «паче остановясь скоро в течении своем, обратилась еще в существительный публике убыток, с повреждением перед оною столь нужного и драгоценного государственного кредита» - повелела покончить «все сие неприятное и скучное дело», в результате чего 20 марта 1964 г. принимается Сенатский указ «О разыгрывании последнего четвертого класса Государственной лотереи и об отпуске денег из казны на уплату всех выигранных лотов».

23 марта 1771 года вышел именной Указ императрицы Екатерины II «О запрещении разыгрывания лотерей в России и брать билеты в иностранных лотереях».

Как отмечается в литературе, с самого момента возникновения лотереи стали объектом законодательного творчества и постоянного правительственного надзора ${ }^{8}$. Так, в начале 1780-х были приняты «Правила о разыгрывании лотерей, с дозволения Правительства, и порядок исходатайствования сего дозволения», вносившие в эту область целый ряд ограничений ${ }^{9}$.

Первые нормы, закрепляющие порядок организации и проведения лотерей, были закреплены в Уставе Благочиния 1782 г. (первоначальное название - «Устав благочиния, или полицейский»), который стал первым полноценным источником правового регулирования лотереи в нашей стране. Устав содержал нормы, которые довольно детально регламентировали деятельность по организации и проведению любых лотерей на территории страны. Уставом было установлено, что лотереи не могли проводиться без дозволения Императора. Лотерейные билеты не могли распространяться без дозволения Управы

\footnotetext{
${ }^{7}$ Иванов А. Лотерейное счастье // Санкт-Петербургские ведомости. Выпуск. Выпуск № 235 от 15.12.2006 г. http://www.spbvedomosti. ru/article.htm?id=10240042@SV_Articles

${ }^{8}$ Северюхин Д.Я. Указ. соч. С. 629.

${ }^{9}$ Северюхин Д.Я. Указ. соч. С. 629.
}

Благочиния. Примечательно, что предметом розыгрыша лотереи могли быть только вещи. На проведение лотереи на сумму свыше тысячи пятисот рублей требовалось Высочайшее разрешение. ${ }^{10}$

В XIX веке благотворительные лотереи являются обычным и привычным для россиян мероприятием. Законом от 5 декабря 1866 г. «Об учреждении приютов и колоний для нравственного исправления несовершеннолетних преступников» ${ }^{11}$ каждому приюту или колонии разрешалось разыгрывать благотворительную лотерею, вырученные от продажи средства поступали в их пользу. К примеру, в Томске каждое 30 или 31 декабря начиная с 1867 года попечительскими комитетами ежегодно проводятся лотереи-аллегри (моментальные лотереи), доходы от которых поступают на нужды комитетов ${ }^{12}$.

Уложение о наказаниях уголовных и исправительных от 1845 г. ${ }^{13}$ устанавливает, что за подлоги и другие обманы при разыгрывании лотереи виновные подвергаются наказаниям, определенным за обманы в игры в карты, кости и т.п.

Принятый в 1857 году во времена правления Александра II Устав о предупреждении и пресечении преступлений уже содержал целую главу посвященную лотереям ${ }^{14}$. Выделим наиболее важные положения Устава о лотереях. Так, разыгрывание лотерей на сумму свыше тысячи пятисот рублей, а также разыгрывание денежных премий и процентных бумаг запрещается. Лотереи же на сумму до тысячи пятисот рублей для разыгрывания вещей, объявление об иностранных лотереях и продажа лотерейных билетов не иначе могут производимы с разрешения правительства. Дозволение на розыгрыши лотерей, по известному вреду от них, должны быть делаемы сколь можно реже и притом только для людей бедных. Вещи к розыгрышу в лотерею оцениваются присяжным ценовщиком и к верно объявленной им цене дозволяется причитать указанные проценты. В более поздней редакции (1895 г.) лотереи на сумму до тысячи пятисот рублей разрешаются министром внутренних дел, а для детских приютов Императорского женского патриотического Общества Главноуправляющим Собственною Его Императорского Величества Канцелярией по Учреждениям Императрицы

\footnotetext{
${ }^{10}$ Российское законодательство X-XX веков. В девяти томах. Т.5. Законодательство периода расцвета абсолютизма. М., 1987. С. 369.

${ }^{11}$ ПСЗ. 1. Спб., 1867. Т. XXXVI. Отд. 1-е. № 36251.

${ }^{12}$ Серякова Н.А. Благотворительность и общественный досуг томичей во второй половине XIX в. (по материалам «Томских губернских ведомостей») // Вестник Томского государственного университета. 2010. №1 (9). С. 58.

${ }^{13}$ Свод законов Российской империи. Том XV. - СПб, издание товарищества «Общественная польза». 1990. С. 93-94.

${ }^{14}$ Свод законов Российской империи. Том XIV. - СПб, издание товарищества «Общественная польза». 1990. С. 90-91.
} 


\section{Право и политика $1(157) \cdot 2013$}

Марии. Число выигрышей в лотереях должно быть не менее одной сотой части всего числа билетов и стоимость выигрышей не менее половины той суммы, на которую лотерея разыгрывается. Устройство на народных общественных гуляньях каких бы то ни было лотерей, в том числе и лотерей-аллегри, воспрещается, однако Министру Внутренних Дел в идее изъятия из сего правила, по особым уважениям, разрешать лотерею-аллегри на таких общественных гуляньях, на которых, независимо от платы за лотерейные билеты, назначается, собственно, за вход на гулянье, особая плата не менее одного рубля.

Изданная в 1864 году третья часть Свода местных узаконений губерний остзейских содержала нормы, регулирующие отдельные виды обязательств, которые были разделены на десять разделов. Пятый раздел был посвящен договорам, основанным на риске: договор игры, лотерея, заклад (пари) и договор страхования ${ }^{15}$.

Правила проведения иностранных лотерей были сформулированы в сборнике присяжного поверенного М.И. Мыш «Об иностранцах в России (сборник узаконений, трактатов и конвенций, с относящимися к ним правительственными и судебными разъяснениями)» ${ }^{16}$.

Правила организации и проведения лотереи получили системную трактовку в так называемом Руководстве для составления деловых бумаг под редакцией В. Максимова ${ }^{17}$.

Изложенное позволяет не согласиться с мнением, что в конце XIX века устройство общественных лотерей в пользу благотворительных организаций получило резко отрицательную оценку ${ }^{18}$. Напротив, как отмечают историки, правительство пошло даже на либерализацию некоторых законоположений, однако лишь в отношении благотворительных лотерей ${ }^{19}$. Вместе с тем нельзя не отметить довольно жесткий контроль за лотереями со стороны государства. Данный вывод можно сделать даже из того обстоятельства, что нормы о лотереях содержатся в актах явно уголовно-правовой направ-

${ }^{15}$ Пахман С.В. История кодификации гражданского права / Под редакцией и с предисловием В.А. Томсинова. - М.: Зерцало, 2004 - (Серия «Русское юридическое наследие»). С. 781.

${ }^{16}$ Мыши М. И. Об иностранцах в России (сборник узаконений, трактатов и конвенций, с относящимися к ним правительственными и судебными разъяснениями). - С.-Петербург, типография Н. А. Лебедева, 1888 // СПС «Гарант».

${ }^{17}$ Руководство для составления деловых бумаг (издание 3-е, переработанное и значительно дополненное) (сост. В. Максимов). Москва, товарищество скоропечатни А. А. Левенсон, 1913 г. С. 1822-1826.

18 Чернега О.А. Правовая модель благотворительности и благотворительных организаций: гражданско-правовой и социологический аспекты. Дис. ... канд. юрид. наук. М., 1998. С. 34.

${ }^{19}$ Павлова И.П. Социальное попечение в России в конце XIX - начале XX века. Дис. ... докт. ист. наук., СПб., 2004. С. 81. ленности. Разумеется, такие акты не могли содержать нормы, которые регулировали бы лотерею как институт гражданского права.

На рубеже XIX и XX веков большие надежды отечественной цивилистики были возложены на новый кодифицированный акт - Гражданское уложение Российской империи. В ставшем впоследствии знаменитым Проекте Гражданского уложения была предусмотрена отдельная глава XXIII под названием «Лотерея» ${ }^{20}$. Таким образом, в российском законодательстве могли появиться первые нормы, регулирующие лотерею как институт гражданского права.

Несмотря на краткость, нормы Проекта отражают основную суть обязательственных отношений между организатором и участником лотереи. Так, Проектом установлено, что между предпринимателем лотереи и лицами, принимающими участие в ее розыгрыше, только в таком случае возникают обязательственные отношения, если лотерея разрешена подлежащею правительственною властью, а сделки по продаже всякого рода промессов на какие бы то ни было лотереи и на билеты займов с выигрышами не пользуются судебною защитою (ст. 2543). Собственник лотерейного билета имеет право на получение выпавшего на него выигрыша (ст. 2544). Присылка лотерейного ж билета лицу, не заявившему о том просьбы, ни к чему лицо это не обязывает. Билет, своевременно не оплаченный, не дает права на выигрыш (ст. 2545). Предприниматель лотереи обязан в назначенное время произвести розыгрыш, хотя бы не все билеты были разобраны, и затем немедленио выдать выпавшие на билеты выигрыши (ст. 2547). Уплаченные за билет деньги могут быть потребованы обратно, хотя бы лотерея была устроена без разрешения правительственной власии, если условленный розыгрыш почему-либо не состоялся (ст. 2547).

Известно, что Гражданское уложение так и не было принято, поэтому первые гражданско-правовые нормы о лотерее не вступили в действие.

После вступления России в первую мировую войну в поддержку пострадавших от войны создаются специальные благотворительные комитеты, которые финансируются в том числе за счет доходов от благотворительных лотерей ${ }^{21} .3$ декабря 1914 было принято Высочайшее повеление об утверждении положения о благотворительной лотерее

\footnotetext{
${ }^{20}$ Гражданское Уложение. Проект Высочайше учрежденной Редакционной Комиссии по составлению Гражданского уложения (с объяснениями, извлеченными из трудов редакционной комиссии) / Сост. А.А. Саатчиан / Под ред. И.М. Тютрюмова, Т.2. СПб., 1910. С. 1162-1163.

${ }^{21}$ Хитров А.А. Дом Романовых и российская Благотворительность. Вторая половина XIX - начало XX века. (По материалам Санкт-Петербурга-Петрограда и Петербургской-Петроградской губернии). Дис. ... докт. ист. наук., СПб, 2009. С. 141-142.
} 
1914 года в пользу раненых и больных воинов, семей лиц, призванных на войну, и лиц, пострадавших от военных бедствий ${ }^{22}$. Пожалуй, это был последний нормативный акт, посвященный правовому регулировании лотереи в дореволюционной России.

А.В. Сохан, давая итоговую характеристику правовому регулированию лотереи в дореволюционной России, приходит к следующим выводам: «в Российской империи «действовал разрешительный порядок проведения лотерей. Допускались исключительно вещевые лотереи и только в благотворительных целях. За проведением лотерей устанавливался строгий контроль. Все это было направлено на то, чтобы минимизировать возможные негативные последствия такого мероприятия и получить от них максимально возможную пользу для общества» ${ }^{23}$.

В целом соглашаясь с указанным автором, добавим, что государством принимался ряд специальных актов, запрещающих или ограничивающих проведение лотерей. Из содержания указанных актов видно, что государство осознавало, что стремительно развивающееся новое развлечение нужно попытаться подвести под рамки закона и подчинить определенным правилам.

Также отметим, что в данный исторический период лотерея не признавалась институтом гражданского права. Действовавшее в тот исторический период российское законодательство не содержало норм, регулирующих договорные отношения между организаторами и участниками лотерей, гражданско-правовое положение сторон договора лотереи, защиту прав участников лотерей, правовой режим призового фонда лотереи. Попытка законодателя ввести нормы, регулирующие лотерею как гражданскоправовой институт, в Проекте Гражданского уложения осталась нереализованной.

\section{Правовое регулирование лотерей в советский период}

Революция 1917 года ознаменовала переход к новой экономической формации, которая разрушила ранее существовавшие экономические отношения. Первые годы после революции государство предприняло довольно жесткие меры по борьбе с азартными играми, а также с лотереями. 19 декабря 1918 г. Совет Народных Комиссаров РСФСР принял декрет «О запрещении устройства лотерей», которым постановил «воспретить устройство лотерей, денежных и вещевых, а также розыгрыш денежных премий». Столь суровая мера прекрасно характеризует крутой нрав советского законодателя,

${ }^{22}$ Собр.указ. №339,11-го декабря 1914 г., ст. 3233. Указанное повеление было приведено в работе О.И. Авербаха «Законодательные акты, вызванные войной 1914-1915 гг. Том 1 (издание 2-е)».

${ }^{23}$ Сохан А.В. Правовое регулирование лотереи в Российской империи // История государства и права. 2011. № 12. С. 4. решившего бороться со всеми пороками царизма, в том числе и аморальными играми.

Однако в последующем молодое государство, остро испытывающее недостаток в средствах, вынуждено было постепенно пересматривать свое отношение к лотереям как к источнику пополнения бюджета. Молодое государство столкнулось с поистине национальным бедствием - голодом в Поволжье. В помощь голодающим 1921 г. организованы лотерея Петроградской Губернской комиссии «Петроград - голодающему Поволжью», лотерея Витебского Губернского комитета помощи голодающим «Витебск голодающему Поволжью», лотерея Севастопольского комитета помощи голодающим Поволжья и т.д.

31 октября 1922 г. Совет народных комиссаров выносит декрет «О государственной лотерее», а 31 мая 1923 г. декрет «О порядке выдачи разрешений на устройство местных лотерей».

Однако 24 июля 1923 г. Совет народных комиссаров CCCP, принял декрет о воспрещении устройства впредь каких бы то ни было лотерей как центральными, так и местными органами на всей территории Союза ССР до 1 января 1924 года, а затем продлил его действие до особого постановления, поэтому государственная лотерея, она же государственная лотерея 1922-1923 года, она же государственная лотерея 1923-1924 года так и не была проведена ${ }^{24}$.

В феврале 1923 г. была объявлена государственная лотерея, которая, по мнению некоторых историков, стала свидетельством возврата к финансовым методам прошлого ${ }^{25}$. Кроме того, лотереи продолжали проводиться местными губернскими комитетами и комиссиями по борьбе с последствиями голода. Также лотереи проводились и в иных социально значимых целях. Так, в октябре 1924 г. в Пскове по просьбе Псковской губдеткомиссии была устроена лотерея, доходы от которой шли на борьбу с детской беспризорностью ${ }^{26}$. В 1925 г. Комиссией по улучшению жизни детей при ВЦИК организована денежная лотерея, доход от которой был направлен на борьбу с беспризорностью.

1 января 1930 г. Совет народных комиссаров СССР выносит постановление «О порядке выдачи разрешений на устройство лотерей», которым установлено, что вы-

\footnotetext{
${ }^{24}$ Теребов В.Н. Лотерейные билеты СССР и РСФСР центральных выпусков // Советский коллекционер. 1989(27). С.168-193. // http:// www.bonistikaweb.ru/SOVKOL/terebov3.htm.

${ }^{25}$ Карр Э. История Советской России. Книга 1-ая. (Том 1 и 2). Большевистская революция. 1917-1923. М., Издательство «Прогресс», 1990. С. 675-676. Видимо, исследователь имеет в виду Всероссийскую денежную лотерею Центрального комитета по борьбе с последствиями голода.

${ }^{26}$ Филимонов А.В. Азартные игры в Пскове в 1920-е // Псков. 2010. № 33. C. 79.
} 


\section{Право и политика $1(157) \cdot 2013$}

дача разрешений на проведение лотерей производится исключительно Правительством СССР. 23 июля 1933 г. Совет народных комиссаров СССР выносит постановление «О порядке выдачи разрешений на устройство лотерей».

Во время Великой Отечественной Войны денежно-вещевые лотереи явились важным средством мобилизации денежных средств. Проведение лотерей осуществлялось в несколько этапов: выпуск лотерейных билетов, подписка на них и оплата подписки. Выигрыши по всем лотереям устанавливались в размере $20 \%$ от их номинальной суммы ${ }^{27}$.

В послевоенные годы государство в целях привлечения средств для пополнения бюджета снова организовывает денежно-вещевые лотереи, которые представляют собой крупные массово-политические акции; распространение лотерейных билетов поручается получающим вознаграждение профессионалам ${ }^{28}$. Так, за период с 1958 по 1979 г. союзными республиками было реализовано лотерейных билетов на сумму 4,6 млрд. рублей ${ }^{29}$.

Большую популярность получили спортивно-числовые лотереи («Спортлото») лотереи ДОСААФ СССР, лотереи «Спринт», Всероссийская книжная лотерея и т.д.

Правовое регулирование лотерей в СССР в период «застоя» подробно исследовано в диссертации Г.И. Стрельниковой. Так, исследователь выделяет следующую систему актов общесоюзного, союзно-республиканского, республиканского и ведомственного значения, которые содержали нормы, регулирующие лотерейную деятельность в СССР. Во-первых, это общие положения Основ гражданского законодательств Союза ССР и союзных республик о сделках, общие положения об обязательствах, регламентирующие порядок заключения договоров, устанавливающие общие меры ответственности за неисполнение сторонами своих обязанностей, а к договорным отношениям применяются соответствующие нормы гражданских кодексов, воспроизводящие, реализующие и развивающие нормы Основ ${ }^{30}$. Во-вторых, постановление СНК СССР от 1 января 1930 г. «О порядке выдачи разрешений на устройство лотерей» ${ }^{31}$. В-третьих,

27 Плотников К.Н. Очерки истории бюджета Советского государства. М., 1955. С.317, Ивлев Н.Н. Деятельность финансовых органов Челябинской области в годы Великой Отечественной Войны // Вестник Челябинского государственного университета. 2009. № 37 (175). История. Вып. 36. С. 104.

${ }^{28}$ Селезнева Е.Ю. Денежно-вещевая лотерея как метод привлечения денежных средств населения Дальневосточного региона в госбюджет в послевоенные годы // Вологдинские чтения. 2007. № 62. С. 93.

${ }^{29}$ Булкин В.И. Лотереи в СССР // Финансы СССР. 1979. №8. С. 72.

${ }^{30}$ Стрельникова Г.И. Гражданско-правовое регулирование организации и проведения лотерей в СССР. Дис. ... канд. юрид. наук. Свердловск, 1983. С. 24-25.

${ }^{31}$ Стрельникова Г.И. Указ. соч. С. 25. постановления и распоряжения Совета министров $\mathrm{CCCP}$, разрешающие проведение той или иной лотереи ${ }^{32}$. Г.И. Стрельникова в качестве примеров приводит распоряжении Совета министров СССР от 19 сентября 1975 г. №2158-р «О проведении в 1976-1980 годах лотерей ДОСААФ СССР», распоряжения Совета министров СССР №800-р от 29 апреля 1970 г. и №31-р от 6 января 1972 г. «О проведении спортивно-числовых лотерей». От себя мы добавим иные примеры: постановление Совета министров РСФСР от 12 декабря 1957 г. «О проведении денежно-вещевой лотереи», постановление Совета министров РСФСР от 14 ноября 1959 г. №1819 «О проведении денежно-вещевой лотереи в 1960 г.», постановление Совета министров СССР от 8 января 1959 г. «О проведении денежно-вещевой лотереи в 1959 г.» и т.д. В-четвертых, нормы Уставов и Положений об организаторах лотерей, устанавливающие, что специальной правосубъектностью данного социального образования среди иных форм деятельности охватывается и проведение лотерей, к примеру, ст. 15 Устава ДОСААФ $\mathrm{CCCP}^{33}$. В-пятых, положения о руководящих органах лотереи, которыми формулируются задачи и функции этих органов, связанные с практическим проведением лотереи, и определяются их права и обязанности ${ }^{34}$. В-шестых, условия каждого выпуска лотерей, к примеру, условия проведения спортивно-числовой лотереи «Спортлото». По мнению Г.И. Стрельниковой, «условия лотерей наиболее общим образом регулируют отношения между организаторами лотерей и собственниками билетов, а также отношения между организациями, осуществляющими проведение данной лотереи» ${ }^{35}$. В-седьмых, инструкции, положения, правила, приказы, инструктивные письма и т.Д., касающиеся проведения какого-либо вида лотерей ${ }^{36}$. Г.И. Стрельникова, довольно критически оценивая систему правового регулирования организации и проведения лотерей в СССР, высказывается о целесообразности издания Советом министров СССР Общего положения о порядке проведения лотерей в СССР, где были бы закреплены основные требования, которым должны отвечать все виды лотерей ${ }^{37}$.

Как отмечает А.В. Сохан, проведение лотерей в советское время помогало государству собрать все необходимые средства на социально-культурное развитие той или иной сферы. Лотереи, как и другие азартные игры, попрежнему влекли растрату их участниками собственных материальных средств, были сопряжены с негативными

\footnotetext{
${ }^{32}$ Стррельникова Г.И. Указ. соч. С. 25.

${ }^{33}$ Стрельникова Г.И. Указ. соч. С. 26.

${ }^{34}$ Стрельникова Г.И. Указ. соч. С. 26.

${ }^{35}$ Стрельникова Г.И. Указ. соч. С. 28.

${ }^{36}$ Стрельникова Г.И. Указ. соч. С. 29.

${ }^{37}$ Стрельникова Г.И. Указ. соч. С. 34.
} 
последствиями для морально-нравственного состояния общества, однако с учетом действовавших правовых норм влекли незначительные последствия данного рода, а в большей степени приносили пользу в виде сбора средств для разрешения социальных задач государства ${ }^{38}$.

В целом соглашаясь с указанными выводами, добавим, что отношение советского государства к лотереям менялось от полного запрета до широкой пропаганды покупки лотерейных билетов. Лотереи доказали свою экономическую состоятельность даже в суровой идеологии сталинской государственной машины, и получили серьезную государственную поддержку в период «оттепели» и «застоя».

Вместе с тем отсутствие четкой системы нормативных актов, регулирующих организацию и проведение советских лотерей, отсутствие понятийного аппарата, позволяет нам сделать вывод, что лотерея, по сути, не рассматривалось государством как правовой институт. Объект правового регулирования существовал и даже был очень распространен, однако. Многочисленные ведомственные акты с правилами конкретных лотерей скорее напоминают публичные оферты, нежели нормативно-правовые акты с четким предметом правового регулирования. Массив актов даже не содержал единого понятия лотереи, призового фонда лотереи, не определяло четкого единого механизма выдачи призов, защиты прав участников лотереи.

\section{Правовое регулирование лотерей в современной России}

С развалом советского государства дикие рыночные отношения вошли во все экономические процессы нового российского государства.

Советские нормативные акты, регулирующие организацию и проведение лотерей, утратили свою силу, а новые акты, регулирующие лотерею уже как бизнес, принимались тяжело. С перерывом в более чем 70 лет появились негосударственные лотереи, опыта регулирования которых у российского законодателя не было.

Первым нормативным актом, посвященным правовому регулированию лотереи в Российской Федерации, стало Постановление Правительства РФ № 114 от 25 февраля 1992 года «О порядке проведения лотерей в Российской Федерации». Затем в течение нескольких лет были приняты Указ Президента РФ № 2049 от 1 ноября 1994 г. «О государственном регулировании спортивных и других видов лотерей», Постановление Правительства РФ № 330 от 15 апреля 1995 года «Об упорядочении проведения лотерей на территории Российской Федерации», которым был утвержден

${ }^{38}$ Сохан А.В. Правовое регулирование лотерей в РСФСР // Право и политика. 2011. №10. С. 1737.
Порядок выдачи разрешений на проведение всероссийских лотерей. Указанные акты не содержали норм, посвященных гражданско-правовому регулированию лотереи, они лишь устанавливали лишь общие правила административного контроля со стороны государства.

Наконец, в сентябре 1995 года было принято Временное положение о лотереях России, утвержденное Указом Президента РФ № 955 от 19 сентября 1995 года «Об упорядочении лотерейной деятельности в Российской Федерации». По справедливому замечанию Ю.В. Багно, Временное положение стало основным нормативным актом, регулирующим отечественную лотерейную деятельность $^{39}$. Так, положением было установлено, что все лотереи, проводимые на территории Российской Федерации, независимо от их типа, вида и территориального статуса, подлежат государственной регистрации. Также данный нормативный акт включал понятие нормы гражданскоправового характера, в том числе понятия лотереи, учредителя, организатора, участника лотереи, положения об отдельных видах лотереи, о лотерейном билете, о призовом фонде лотереи. В положении используются термины «обязательство», «собственность», что не было характерно для отечественного законодателя.

К недостаткам Временного положения следует отнести то, что содержащиеся в нем нормы распространялись также на тотализаторы и системные (электронные) игры, без учета их правовой специфики. Слишком много внимания уделяется вопросам прав автора лотереи. Как минимум спорным моментом является то, что в каждой лотерее подлежат авторское право на лотерею, и если авторство невозможно установить, то такая лотерея регистрируется как безымянная и т.д. В то же время не закрепляются права участника лотереи, механизм защиты прав участника лотереи. Недостатки Временного положения объясняются тем, что оно, по сути, является актом переходным, и действует до принятия специального федерального закона.

1 марта 1996 года вступил в силу часть вторая Гражданского кодекса Российской Федерации. Напрямую лотерее в ГК РФ посвящена лишь одна статья 1063, в соответствии с которой отношения между организаторами лотерей, тотализаторов (взаимных пари) и других основанных на риске игр - Российской Федерацией, субъектами Российской Федерации, муниципальными образованиями, лицами, а для лотерей - юридическими лицами, получившими от уполномоченного государственного или муниципального органа право на проведение таких игр в порядке, установленном законом - и участниками игр основаны на договоре. Между тем, разумеется, столь сложное правовое явление, как лотерея, нуждалось в более развернутом

${ }^{39}$ Багно Ю.В. Гражданско-правовое регулирование лотерейного договора // Законодательство. 2004. №4 // СПС «Гарант». 


\section{Право и политика 1 (157) 2013}

и основательном регулировании, нежели одной-единственной статьей в ГК РФ.

При наличии действующего Временного положения некоторые субъекты Российской Федерации издавали свои законодательные акты. В качестве примера можно привести Закон г. Москвы от 28 апреля 1999 г. №18«О проведении лотерей и регулировании лотерейной деятельности в Москве», нормы которого фактически дублировали содержание Временного положения о лотереях, Постановление Администрации Нижегородской области от 11 января 1996 г. №13 «Об упорядочении лотерейной деятельности на территории Нижегородской области (вместе с Временым положением об организации проведении лотерей в Нижегородской области)».

Анализируя сложившуюся в 90-х годах ситуацию с правовой регламентацией лотереи, Ю.В. Багно справедливо отмечает, что большое количество подзаконных актов, действовавших в данной сфере создавало неопределенность и обнаруживало отсутствие последовательной государственной программы в области лотерейной деятельности, а принимаемые государством подзаконные акты в основном были направлены на учреждение и регистрацию лотерей, их организационное оформление, отодвигая на второй план защиту интересов их участников ${ }^{40}$.

Находившееся в условиях кризиса и разгула криминала, в том числе экономического, российское государство остро нуждалось в принятии единых нормативных актов во многих сферах экономики. Очевидна была необходимость принятия федерального закона, который бы регулировал организацию и проведение лотерей в Российской Федерации. Одной статьи ГК РФ явно было недостаточно, а из самого названия Временного положения о лотереях видно, что оно носит временный характер и должно было действовать до принятия специального федерального закона о лотереях. Временное регулирование лотерей в постсоветской России затянулось на восемь долгих лет.

11 ноября 2003 года был принят специальный Федеральный закон №138-Ф3 «О лотереях», вступивший в законную силу 1 января 2004 г., который на сегодняшний день является стержневым нормативным актом, регулирующим лотереи в Российской Федерации. За трехсотлетнюю историю лотерей в нашей стране он стал первым законом, который специализированно посвящен правовому регулированию лотерей.

Закон содержит нормы, регулирующие организацию и проведение лотерей, в том числе виды и цели проведения лотерей, порядок их организации и проведения на территории Российской Федерации обязательные нормативы лотерей, порядок осуществления контроля за их организацией и проведением; требования к лотерейным билетам,

${ }^{40}$ Багно Ю.В. Гражданско-правовое регулирование лотерейного договора // Законодательство. 2004. №4 // СПС «Гарант». права, обязанности, ответственность организаторов, операторов и участников лотерей. Большим достоинством закона является детальная регламентации лотереи как гражданско-правового института.

За менее, чем за десять лет действия Федерального закона «О лотереях» в него вносились многочисленные изменения и дополнения, что свидетельствует о сложности и противоречивости регулируемых данным законом общественных отношений. Серьезные изменения в Федеральный закон «О лотереях» предлагаются и на момент опубликования настоящей статьи. В частности, высказывается идеи о полном запрете негосударственных лотерей и даже об ограничении проведения лотерей по аналогии с азартными играми.

Следует признать, что правовое регулирование лотерей в России имело довольно длительную и тяжелую историю. Лотереи то запрещались, то получали поддержку со стороны государства, но неизменно имели популярность у наших сограждан. Проблемы, с которым столкнулся и до сих пор не может удачно решить современный законодатель, связаны со следующим. Правовое регулирование лотерей прошло период фактического отсутствия правовых норм и стихийных запретов (с XVIII в. до Октябрьской революции), советский правопорядок с громоздкими и очень многочисленными, но малоэффективными ведомственными актами, характерными для советского законодательства. С начала 90-х годов XX века выяснилось, что у отечественного законодателя просто нет того исторического опыта, которым можно было бы руководствоваться при принятии конкретных норм и правовых категорий. Не были исторически выработаны правовые категории, понятийный аппарат, не выработалась единообразная практика защиты прав участников лотерей. И первый Федеральный закон «О лотереях» ждет тяжелое испытание временем.

История осмысленного правового регулирования лотерей как полноценного института права только начинается.

\section{Библиография:}

1. Багно Ю.В. Гражданско-правовое регулирование лотерейного договора // Законодательство. 2004. №4 // СПС «Гарант».

2. Булкин В.И. Лотереи в СССР // Финансы СССР. 1979. №8.

3. Гражданское Уложение. Проект Высочайше учрежденной Редакционной Комиссии по составлению Гражданского уложения (с объяснениями, извлеченными из трудов редакционной комиссии) / Сост. А.А. Саатчиан / Под ред. И.М. Тютрюмова, Т.2. СПб., 1910. 
4. Записки Желябужского с 1682 по 2 июля 1709 г.. СПб.: Типография Императорской Российской Академии, 1840.

5. Иванов А. Лотерейное счастье // Санкт-Петербургские ведомости. Выпуск. Выпуск № 235 от 15.12.2006 г.

6. Ивлев Н.Н. Деятельность финансовых органов Челябинской области в годы Великой Отечественной Войны // Вестник Челябинского государственного университета. 2009. № 37 (175). История. Вып. 36.

7. Карр Э. История Советской России. Книга 1-ая. (Том 1 и 2). Большевистская революция. 1917-1923. М., Издательство «Прогресс», 1990.

8. Маргвелашвили В. Первая лотерея на Руси // Молодая гвардия. 1967. № 3.

9. Мыш М. И. Об иностранцах в России (сборник узаконений, трактатов и конвенций, с относящимися к ним правительственными и судебными разъяснениями). - С.-Петербург, типография Н. А. Лебедева, 1888 // СПС «Гарант».

10. Павлова И.П. Социальное попечение в России в конце XIX - начале XX века. Дис. ... докт. ист. наук., СПб., 2004.

11. Пахман С.В. История кодификации гражданского права / Под редакцией и с предисловием В.А. Томсинова. - М.: Зерцало, 2004 - (Серия «Русское юридическое наследие»).

12. Плотников К.Н. Очерки истории бюджета Советского государства. М., 1955.

13. ПСЗ. 1. Спб., 1867. Т. XXXVI. Отд. 1-е. № 36251.

14. Российское законодательство X-XX веков. В девяти томах. Т.5. Законодательство периода расцвета абсолютизма. М., 1987.

15. Руководство для составления деловых бумаг (издание 3-е, переработанное и значительно дополненное) (сост. В. Максимов). - Москва, товарищество скоропечатни А. А. Левенсон, 1913 г.

16. Северюхин Д.Я. Художественный рынок СанктПетербурга - Петрограда - Ленинграда, его роль и значение в истории развитии отечественного изобразительного искусства // Автореф. дис. ... докт. иск.. наук. М., 2010.

17. Северюхин Д.Я. Художественный рынок СанктПетербурга - Петрограда - Ленинграда, его роль и значение в истории развитии отечественного изобразительного искусства // Дис. ... докт. иск.. наук. M., 2010.

18. Селезнева Е.Ю. Денежно-вещевая лотерея как метод привлечения денежных средств населения Дальневосточного региона в госбюджет в послевоенные годы // Вологдинские чтения. 2007. № 62.

19. Серякова Н.А. Благотворительность и общественный досуг томичей во второй половине XIX в. (по материалам «Томских губернских ведомостей») //
Вестник Томского государственного университета. 2010. №1 (9).

20. Сохан А.В. Правовое регулирование лотереи в Российской империи // История государства и права. 2011. № 12 .

21. Сохан А.В. Правовое регулирование лотерей в РСФСР // Право и политика. 2011. №10.

22. Стрельникова Г.И. Гражданско-правовое регулирование организации и проведения лотерей в СССР. Дис. ... канд. юрид. наук. Свердловск, 1983.

23. Теребов В.Н. Лотерейные билеты СССР и РСФСР центральных выпусков // Советский коллекционер. 1989(27).

24. Филимонов А.В. Азартные игры в Пскове в 1920-е // Псков. 2010. № 33.

25. Хитров А.А. Дом Романовых и российская Благотворительность. Вторая половина ХІХ - начало XX века. (По материалам Санкт-ПетербургаПетрограда и Петербургской-Петроградской губернии). Дис. ... докт. ист. наук., СПб, 2009.

26. Чернега О.А. Правовая модель благотворительности и благотворительных организаций: гражданско-правовой и социологический аспекты. Дис. ... канд. юрид. наук. М., 1998.

27. Энциклопедический словарь / под ред. проф. И. Е. Андреевского. Санкт-Петербург: Ф. А. Брокгауз, И. А. Ефрон, 1890-1907. Т. 18. Лопари - малолетние преступники. 1896.

\section{References (transliteration):}

1. Bagno Yu.V. Grazhdansko-pravovoe regulirovanie lotereynogo dogovora // Zakonodatel'stvo. 2004. №4 // SPS «Garant».

2. Bulkin V.I. Loterei v SSSR // Finansy SSSR. 1979. №8.

3. Ivanov A. Lotereynoe schast'e // Sankt-Peterburgskie vedomosti. Vypusk. Vypusk № 235 ot 15.12.2006 g.

4. Ivlev N.N. Deyatel'nost' finansovykh organov Chelyabinskoy oblasti v gody Velikoy Otechestvennoy Voyny // Vestnik Chelyabinskogo gosudarstvennogo universiteta. 2009. № 37 (175). Istoriya. Vyp. 36.

5. Karr E. Istoriya Sovetskoy Rossii. Kniga 1-aya. (Tom 1 i 2). Bol'shevistskaya revolyutsiya. 19171923. M., Izdatel'stvo «Progress», 1990.

6. Margvelashvili V. Pervaya lotereya na Rusi // Molodaya gvardiya. 1967. № 3.

7. Mysh M. I. Ob inostrantsakh v Rossii (sbornik uzakoneniy, traktatov i konventsiy, s otnosyashchimisya $\mathrm{k}$ nim pravitel'stvennymi i sudebnymi raz'yasneniyami). - S.Peterburg, tipografiya N. A. Lebedeva, 1888 // SPS «Garant».

8. Pavlova I.P. Sotsial'noe popechenie v Rossii v kontse XIX - nachale XX veka. Dis. ... dokt. ist. nauk., SPb., 2004. 


\section{Право и политика $1(157) \cdot 2013$}

9. Pakhman S.V. Istoriya kodifikatsii grazhdanskogo prava / Pod redaktsiey i s predisloviem V.A. Tomsinova. - M.: Zertsalo, 2004-(Seriya «Russkoe yuridicheskoe nasledie»).

10. 10.Plotnikov K.N. Ocherki istorii byudzheta Sovetskogo gosudarstva. M., 1955.

11. Severyukhin D.Ya. Khudozhestvennyy rynok SanktPeterburga - Petrograda - Leningrada, ego rol' i znachenie $\mathrm{v}$ istorii razvitii otechestvennogo izobrazitel'nogo iskusstva // Avtoref. dis. ... dokt. isk.. nauk. M., 2010.

12. Severyukhin D.Ya. Khudozhestvennyy rynok SanktPeterburga - Petrograda - Leningrada, ego rol' i znachenie $\mathrm{v}$ istorii razvitii otechestvennogo izobrazitel'nogo iskusstva // Dis. ... dokt. isk.. nauk. M., 2010.

13. Selezneva E.Yu. Denezhno-veshchevaya lotereya kak metod privlecheniya denezhnykh sredstv naseleniya Dal'nevostochnogo regiona $\mathrm{v}$ gosbyudzhet v poslevoennye gody // Vologdinskie chteniya. 2007. № 62 .

14. Seryakova N.A. Blagotvoritel'nost' i obshchestvennyy dosug tomichey vo vtoroy polovine XIX v. (po materialam «Tomskikh gubernskikh vedomostey»)// Vestnik Tomskogo gosudarstvennogo universiteta. 2010. №1 (9).
15. Sokhan A.V. Pravovoe regulirovanie loterei v Rossiyskoy imperii // Istoriya gosudarstva i prava. 2011. № 12.

16. Sokhan A.V. Pravovoe regulirovanie loterey v RSFSR // Pravo i politika. 2011. №10.

17. Strel'nikova G.I. Grazhdansko-pravovoe regulirovanie organizatsii i provedeniya loterey v SSSR. Dis. ... kand. yurid. nauk. Sverdlovsk, 1983.

18. Terebov V.N. Lotereynye bilety SSSR i RSFSR tsentral'nykh vypuskov // Sovetskiy kollektsioner. 1989(27).

19. Filimonov A.V. Azartnye igry v Pskove v 1920-e // Pskov. 2010. № 33.

20. Khitrov A.A. Dom Romanovykh i rossiyskaya Blagotvoritel'nost'. Vtoraya polovina XIX - nachalo XX veka. (Po materialam Sankt-Peterburga-Petrograda i Peterburgskoy-Petrogradskoy gubernii). Dis. ... dokt. ist. nauk., SPb, 2009.

21. Chernega O.A. Pravovaya model' blagotvoritel'nosti i blagotvoritel'nykh organizatsiy: grazhdansko-pravovoy i sotsiologicheskiy aspekty. Dis. ... kand. yurid. nauk. M., 1998. 